\title{
POST-TRANSLATIONAL MODIFICATION AND EVOKED RELEASE OF TWO LARGE SURFACE PROTEINS OF SYMPATHETIC NEURONS ${ }^{1}$
}

\author{
KATHLEEN J. SWEADNER ${ }^{2}$
}

Department of Neurobiology, Harvard Medical School, Boston, Massachusetts 02114

Received February 24, 1983; Revised May 23, 1983; Accepted June 29, 1983

\begin{abstract}
Two high molecular weight glycoproteins, exposed on the surface of sympathetic neurons, are modified after they have been translated, glycosylated, and inserted in the plasma membrane. B1 (apparent $M_{\mathrm{r}}=230,000$ by electrophoresis in sodium dodecyl sulfate) and B3 $\left(M_{\mathrm{r}} \sim 200,000\right)$ are each modified to give proteins of lower apparent molecular weight: B2 $\left(M_{\mathrm{r}} \sim 215,000\right)$ and B4 $\left(M_{\mathrm{r}}\right.$ $\sim 185,000)$. B1 and B3 are derived from two precursors, P1 $\left(M_{\mathrm{r}} \sim 210,000\right)$ and P3 $\left(M_{\mathrm{r}} \sim 185,000\right)$ which are nonsialylated, mannose-rich proteins not exposed on the cell surface. In unstimulated cells, B1 and B3 are converted to B2 and B4 with a half-life of 4 to $6 \mathrm{hr}$. In cells which have been treated chemically to evoke the release of neurotransmitter, the modification appears to be accelerated, and B2 and B4 are shed into the medium in soluble form (S2 and S4). This evoked release of protein is calcium dependent and is detected only in conditions which favor the rapid release of neurotransmitter. In the absence of exogenous calcium, however, transmitter release can be evoked without the accompanying release of protein. Thus the release of protein is not an essential step of transmitter release, but may follow it.

$\mathrm{B} 1$, its precursor, and derivatives are immunologically related to the NILE (nerve growth factorinducible, large external) ylycoprotein of pheochromocytma PC12 cells (McGuire, J. C., L. A. Greene, and A. V. Furano (1978) Cell 15: 357-365). B3 does not cross-react with B1 or NILE antigenically, but otherwise is synthesized, processed, and released in a similar manner.
\end{abstract}

The cell surface components of sympathetic ncurons can be analyzed in the virtual absence of non-neuronal cells when the neurons are grown in primary cell culture (Estridge and Bunge, 1978; Braun et al., 1981). The cultures express characteristic glycoproteins, glycolipids, and antigens (Estridge and Bunge, 1978; Chun et al., 1980; Braun et al., 1981; Schwab and Landis, 1981; Zurn, 1982 ), and they secrete soluble proteins into the medium (Sweadner, 1981). The expression of two cell surface glycoproteins (Braun et al., 1981) and four secreted pro-

${ }^{1}$ I would like to thank P. H. Patterson, in whose laboratory this work was done, for his advice, support, and encouragement, and L. L. Y. Chun and S. R. J. Salton for the generous gift of antibodies. This work was supported by grants from the National Institute of Neurological and Communicative Disorders and Stroke and the Rita Allen and McKnight Foundations to P. H. Patterson, and by a grant from the Milton Fund to K. J. S. K. J. S. was supported by fellowships from the Charles A. King Trust and from the Muscular Dystrophy Association.

A preliminary report of this work has appeared (Sweadner and Patterson, 1981).

${ }^{2}$ Present address: Neurosurgical Research, Massachusetts General Hospital, Boston, MA 02114. teins (Sweadner, 1981) was previously shown to be correlated with the expression of noradrenergic or cholinergic phenotype. The major cell surface proteins, however, are shared by both the noradrenergic and cholinergic sympathetic neurons (Braun et al., 1981). Of particular interest is a discrete family of four high molecular weight, acidic glycoproteins, two of which are released into the medium when transmitter release is evoked by various chemical means (Sweadner and Patterson, 1981; Sweadner, 1981).

Evidence is presented here that the four high molecular weight, acidic, and releasable glycoproteins are actually the modified and unmodified forms of two different proteins, and that post-translational modification precedes release of the proteins from the cell surface. One of these proteins (B1), its precursor (P1), and its modified derivatives (B2 and S2) are shown to be immunologically related to the nerve growth factor-inducible, large external (NILE) glycoprotein described by McGuire et al. (1978), which has been found to be expressed in a variety of neurons in both the peripheral and central nervous systems (Salton et al., 1983; Stallcup et al., 1983; 
L. L. Y. Chun, manuscript in preparation). The accompanying paper (Sweadner, 1983) presents hydrodynamic evidence that the proteins are shaped like elongated rods, and that they are released into the medium as monomers in solution.

\section{Materials and Methods}

Cell culture. Primary cultures of sympathetic neurons from the superior cervical ganglion of the newborn rat were prepared as described previously (Hawrot and Patterson, 1979), with the exception that desheathed ganglia were dissociated by incubation in $5 \mathrm{mg} / \mathrm{ml}$ of dispase (Boehringer Mannheim, Indianapolis, IN) at $37^{\circ} \mathrm{C}$ for 1 hr. The suspension was triturated first with a fire-polished Pasteur pipette, and then undissociated chunks of tissue were triturated with a 22 gauge syringe. Cultures of 1000 to 2000 cells were maintained as described previously (Hawrot and Patterson, 1979; Braun et al., 1981) in 8-mm-diameter wells to facilitate biochemical analysis. Non-neuronal cells were eliminated with arabinosylcytosine. All experiments were performed on cells that had been in culture for at least 3 weeks. When adrenergic and cholinergic cultures were to be compared, sister cultures were fed medium containing $20 \mathrm{mM} \mathrm{K}^{+}$or medium conditioned by cultured rat heart cells, respectively, from the 2nd day after plating the cells (Sweadner, 1981).

The pheochromocytoma PC12 cell line was obtained from J. A. Wagner, Harvard Medical School, and was maintained as described (Greene and Tischler, 1976). For radioactive labeling, cells were plated in 8-mm-diameter wells and grown for 8 days with or without nerve growth factor.

Protein labeling and gel electrophoresis. In all experiments, proteins were detected by autoradiography of extracts of labeled cells, resolved by one- or two-dimensional gel electrophoresis. Isotopes $\left(\mathrm{L}-\left[4,5-{ }^{3} \mathrm{H}\right]\right.$ leucine, $\mathrm{L}-$ $\left[6-{ }^{3} \mathrm{H}\right]$ fucose, $\mathrm{D}-\left[2-{ }^{3} \mathrm{H}\right]$ mannose, $\mathrm{L}-\left[{ }^{35} \mathrm{~S}\right]$ methionine, and ${ }^{125} \mathrm{I}$ ) were obtained from New England Nuclear, Boston, MA. Cultures were metabolically labeled with $\left[{ }^{3} \mathrm{H}\right]$ fucose or $\left[{ }^{3} \mathrm{H}\right]$ mannose in complete culture medium, or with $\left[{ }^{3} \mathrm{H}\right]$ leucine or $\left[{ }^{35} \mathrm{~S}\right]$ methionine in medium deficient in $\mathbf{L}$ leucine or L-methionine (custom formulation, Grand Island Biological Co., Grand Island, NY). Each well received 50 to $100 \mu \mathrm{Ci}$ of label for 18 to $24 \mathrm{hr}$, or for $1 \mathrm{hr}$ in pulse-chase experiments. Unlabeled methionine was added to bring the final concentration to 5 to $10 \mu \mathrm{M}$ when $\left[{ }^{35} \mathrm{~S}\right]$ methionine was used, but other isotopes were used without unlabeled carrier. Cell surface proteins were also labeled by lactoperoxidase-catalyzed iodination with ${ }^{125} \mathrm{I}$ as previously described (Hubbard and Cohn, 1976; Braun et al., 1981).

Two-dimensional gel electrophoresis was by the method of O'Farrell and O'Farrell (1976) except that the proteins were initially solubilized with sodium dodecyl sulfate (Ames and Nikaido, 1976), and the isoelectric focusing gels contained $2 \% \mathrm{pH} 3.5$ to $\mathrm{pH} 10$ and $0.5 \%$ pH 5 to $\mathrm{pH} 7$ ampholytes (LKB Instruments, Inc., Gaithersburg, MD). One-dimensional gel electrophoresis was done in slab gels, using the buffer system of Laemmli (1970). Detection of the tritium-labeled bands was by fluorography at $-70^{\circ} \mathrm{C}$ (Bonner and Laskey, 1974), using Kodak X-AR film and DuPont Kronex Lighting-Plus intensifying screens to enhance the sensitivity. Autoradiography of ${ }^{1 \% 5}$ I was performed without fluorography, but intensifying screens were sometimes used to enhance sensitivity.

Antibody precipitation. Labeled proteins were precipitated with antibody-coated, fixed Staphylococcus aureus (Staph A) (Zysorbin; Zymed Laboratories, Burlingame, CA) by the method of Ivarie and Jones (1979), using a buffer containing $0.15 \mathrm{M} \mathrm{NaCl}, 10 \mathrm{~mm}$ Tris-Cl, $\mathrm{pH} 8.0,1$ mM EDTA, and 0.5\% Nonidet P-40 (NP-40) (Particle Data, Inc., Elmhurst, IL). When monoclonal antibodies were used, the Staph A preparation was coated first with excess rabbit anti-mouse purified IgG fraction (N. L. Cappel Laboratories, Cochranville, PA), then with excess mouse monoclonal antibody, and finally with the labeled cell extract. When a polyclonal antiserum was used, the Staph A preparation was coated directly. The final pellet of washed Staph A/antibody/protein complex was extracted with $1 \%$ sodium dodecyl sulfate, and the insoluble Staph A was removed by centrifugation. The extracts were then analyzed by one- or two-dimensional gel electrophoresis and autoradiography.

Evoked release of protein. Reagents used included black widow spider venom (the gift of A. Mauro, Rockefeller University); veratridine, tetrodotoxin, and $p$-chloromercuribenzene sulfonic acid (pCMBS) (Sigma Chemical Co., St. Louis, MO); A23187 and monensin (Eli Lilly and Co., Indianapolis, IN); and alamethicin (The Upjohn Co., Kalamazoo, MI). Neuraminidase (type IX, Clostridium perfringens), trypsin (type III), and soybean trypsin inhibitor (type I-S) were obtained from Sigma. Protease inhibitors phenylmethylsulfonyl fluoride, chloroquine, leupeptin, aprotinin, and diisopropyl fluorophosphate were obtained from Sigma, and pepstatin, chymostatin, and Ep475 were the gift of L. Waxman, Harvard Medical School.

Protein release experiments were performed on cultures that were labeled by the metabolic incorporation of $\mathrm{L}-\left[{ }^{3} \mathrm{H}\right]$ leucine, $\mathrm{L}-\left[{ }^{3} \mathrm{H}\right]$ fucose, or L- $\left[{ }^{35} \mathrm{~S}\right]$ methionine. The experiments were carried out in wells bored in $35-\mathrm{mm}$ Pctri dishes, each well with a volumc of 40 to $50 \mu \mathrm{l}$; this made it possible to collect the proteins released from 1000 to 2000 cells in a small volume. To minimize evaporation, culture dishes were incubated in humidified Petri dish chambers. Cultures were labeled overnight and were washed with a minimal salts solution containing $140 \mathrm{~mm} \mathrm{NaCl}, 5.4 \mathrm{mM} \mathrm{KCl}, 1.2 \mathrm{mM} \mathrm{CaCl}_{2}, 1.0 \mathrm{mM} \mathrm{MgCl}_{2}$, 1.5 mMHEPES-Tris buffer, $\mathrm{pH} 7.2$, and $10 \mathrm{~mm}$ glucose. They were then incubated in the same solution for 30 $\min$ at $36^{\circ} \mathrm{C}$ in an air atmosphere to assess the hackground release of labeled proteins, and then with the test reagent, for three or four 30-min periods. After each 30min period, the solution was removed and a fresh aliquot was added to the cells. When reagents were used which do not readily dissociate from cells, such as pCMBS, A23187, alamethicin, or monensin, the reagent was added only during the first 30-min period; in subsequent periods the cells were given minimal salts solution. Normally, 5$\mu \mathrm{l}$ samples of each aliquot of released protein were electrophoresed on a one-dimensional gel, or 25- $\mu \mathrm{l}$ aliquots were electrophoresed on isoelectric focusing gels for twodimensional separations. 
In control experiments, it was found that release of protein occurs equally well in complete medium with serum and in a $5 \% \mathrm{CO}_{2}$ atmosphere. Experiments were performed in minimal salts in an air atmosphere to avoid the fluctuations of $\mathrm{pH}$ seen when bicarbonate-containing media are used, and serum was not normally included because it limits the volume of sample that can be electrophoresed without distorting bands.

Norepinephrine release. Cultures were loaded with L$\left[2,5,6-{ }^{3} \mathrm{H}\right]$ norepinephrine (New England Nuclear) by incubating them for $1 \mathrm{hr}$ with $5 \mu \mathrm{Ci}$ of exogenous norepinephrine in $1 \mathrm{ml}$ of culture medium. The cultures were then washed three times with minimal salts solution and preincubated in $50 \mu \mathrm{l}$ of minimal salts for $30 \mathrm{~min}$ to $1 \mathrm{hr}$ to allow the deamination and excretion of cytoplasmic $\left[{ }^{3} \mathrm{H}\right]$ norepinephrine. Patterson et al. (1976) found that the majority of norepinephrine remaining in the cells is reserpine sensitive and is stored in a particulate fraction, presumably the synaptic vesicles. The rate of release of tritium is then followed by changing the salts solution every $30 \mathrm{~min}$ or $1 \mathrm{hr}$, and measuring the radioactivity released and that remaining in the cells at the end of the experiment.

\section{Results}

Post-translational modification of NILE-related proteins. Two-dimensional gel electrophoresis of $\left[{ }^{3} \mathrm{H}\right]$ fucoselabeled proteins extracted from cultured sympathetic neurons with NP-40 reveals a cluster of four bands which are of higher molecular weight and more acidic than the majority of other proteins (Fig. 1A, inset). Their apparent molecular weights, as determined by comparison with unglycosylated standard proteins on a one-dimensional gel of $5 \%$ acrylamide, are $\sim 230,000,215,000,200,000$, and 185,000 , and they are called B1, B2, B3, and B4. They have a characteristic spot shape, elongated in the isoelectric focusing dimension. B2 and B4 are sometimes slightly more acidic and sometimes slightly more basic than B1 and B3. Previous work (Braun et al., 1981) has shown that these proteins are labeled when the cells are allowed to incorporate $\mathrm{L}-\left[{ }^{3} \mathrm{H}\right]$ leucine, $\mathrm{L}-\left[{ }^{35} \mathrm{~S}\right]$ methionine, or $\mathrm{L}-\left[{ }^{3} \mathrm{H}\right]$ fucose, which indicates that they are glycopro-
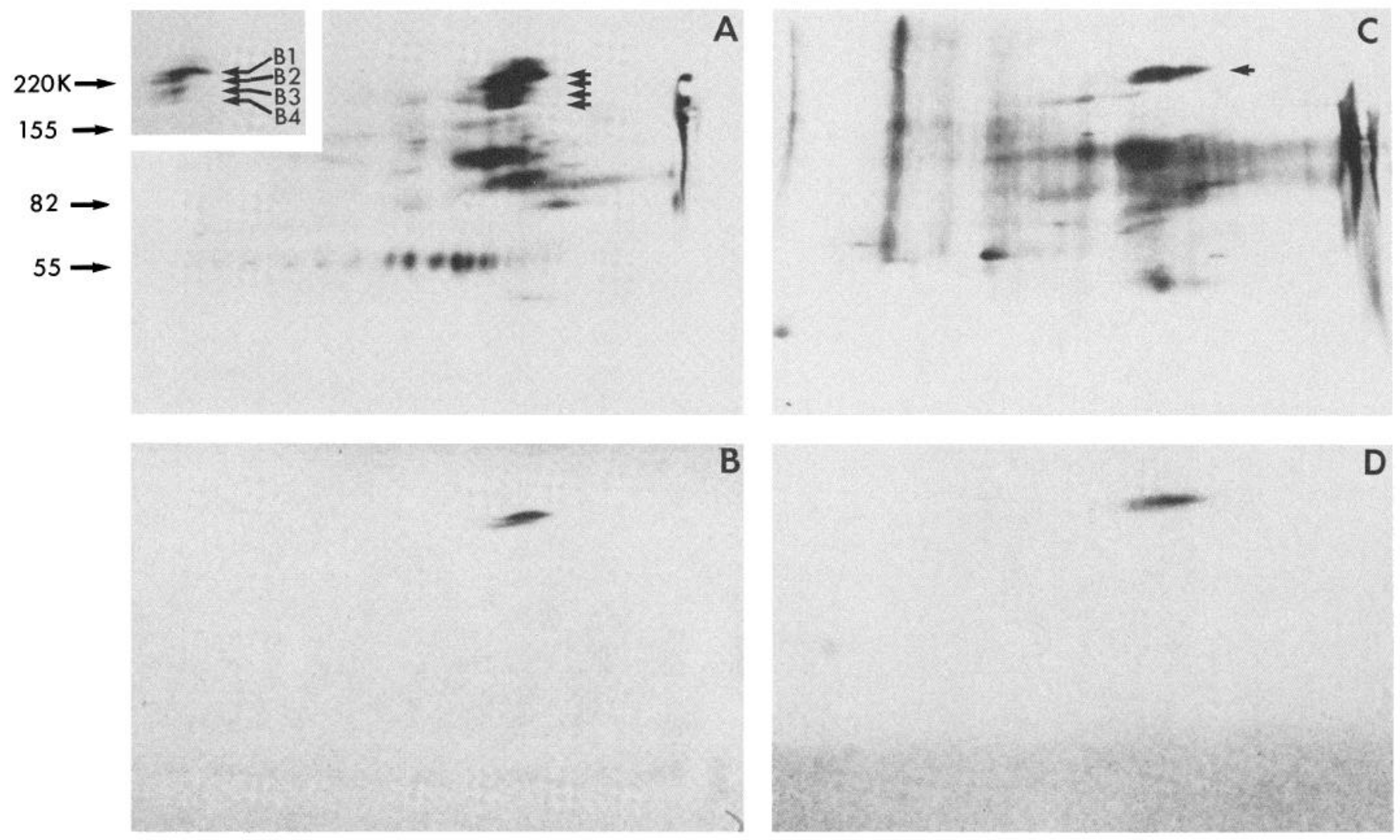

Figure 1. Monoclonal antibody precipitation of $\left[{ }^{3} \mathrm{H}\right]$ fucose-labeled neuronal and PC12 proteins. Cultured superior cervical ganglion neurons and $\mathrm{PC} 12$ pheochromocytoma cells were labeled with $\left[{ }^{3} \mathrm{H}\right]$ fucose overnight, and NP-40 extracts were precipitated with Staph A (Zysorbin) coated with monoclonal antibody ASCS4. Aliquots of the extracts and the precipitates were solubilized in sodium dodecyl sulfate and electrophoresed on two-dimensional gels. $A$, Neuronal glycoproteins; $B$, antibody ASCS4 precipitate of neuronal glycoproteins; $C$, PC12 glycoproteins; $D$, antibody ASCS4 precipitate of PC12 glycoproteins. The pH gradient (from left to right) is from $\mathrm{pH} 8.0$ to $\mathrm{pH} 4.3$, and $\mathrm{B} 1, \mathrm{~B} 2$, B3, and $\mathrm{B} 4(A$, arrows) focus from approximately $\mathrm{pH} 5.3$ to 5.8 . They are resolved as individual spots on a shorter exposure of gel $A$ (inset). The NILE protein is indicated by the arrow in gel $C$; shorter exposures did not reveal any substructure in this spot. The gels were gradients of 5 to $15 \%$ acrylamide. The molecular weights (in thousands $(K)$ ) of previously characterized proteins (Braun et al., 1981) are indicated on the left. 
teins synthesized by the cells, and not constituents derived from the culture medium or substratum. That they are exposed on the cell surface was suggested by several experiments: that they can also be labeled (1) by lactoperoxidase-catalyzed iodination; (2) by periodate oxidation of sialic acid residues, followed by reduction with tritiated borohydride; (3) by galactose oxidase-catalyzed oxidation of galactose or galactosamine residues, followed by reduction with borohydride; and (4) by the fact that their isoelectric points are shifted to a more basic position when sialic acids are removed by treatment of intact cells with neuraminidase (Braun et al., 1981).

In both molecular weight and isoelectric point, the largest of this family of proteins, B1, resembles the NILE cell surface protein first described by McGuire et al., (1978). The relationship of B1, B2, B3, and B4 to the NILE protein of PC12 cells was tested by their antigenic cross-reactivity. A monoclonal antibody (ASCS4) previously shown to bind to the cell surface of sympathetic neurons and to react with a protein of $M_{\mathrm{r}}=230,000$ was obtained from L. Chun, Harvard Medical School (L. L. Y. Chun, manuscript in preparation). This antibody was used to precipitate $\left[{ }^{3} \mathrm{H}\right]$ fucose-labeled proteins from primary cultures of sympathetic neurons and from PC12 cells, using fixed Staph A as an adsorbant for the antigenantibody complexes. Figure $1, A$ and $C$, shows the twodimensional gel patterns of total fucose-containing glycoproteins of sympathetic neurons and PC12 cells, respectively. It is characteristic that the glycoproteins from the PC12 cells appear much less tightly focused in both dimensions. Figure $1, B$ and $D$, shows the precipitates obtained with monoclonal antibody ASCS4. The antibody precipitated proteins $\mathrm{B} 1$ and $\mathrm{B} 2$ from the neuronal extract and the NILE protein from the PC12 extract. Autoradiograms of control precipitates (no antibody) were blank. Proteins B3 and B4 were not precipitated, and no proteins corresponding to proteins B2, B3, and $\mathrm{B} 4$ were resolved in the $\mathrm{PC} 12$ extracts.

A polyclonal antiserum against purified NILE protein from PC12 cells was obtained from S. Salton and L. Greene, New York University Medical Center (Salton et al., 1983). This antiserum was also used to precipitate $\left[{ }^{3} \mathrm{H}\right]$ fucose-labeled neuronal proteins and was found to precipitate the same bands as the monoclonal antibody, and with higher yields (not shown). Thus proteins B1 and B2 are related to each other but are different from proteins $\mathrm{B} 3$ and $\mathrm{B} 4$, and proteins $\mathrm{B} 1$ and $\mathrm{B} 2$ are related to NILE.

Pulse-chase labeling and antibody precipitation provide evidence for the sequential processing of the proteins from two precursor forms, P1 and P3: P1 $\rightarrow \mathrm{B} 1 \rightarrow$ $\mathrm{B} 2$, and in parallel P3 $\rightarrow \mathrm{B} 3 \rightarrow \mathrm{B} 4$. Dense cultures of sympathetic neurons ( 2000 to 3000 cells/8-mm-diameter well) were labeled for $1 \mathrm{hr}$ with $100 \mu \mathrm{Ci}$ of $\left[{ }^{3} \mathrm{H}\right]$ leucine and then were returned to medium containing unlabeled leucine for from 0 to $16 \mathrm{hr}$. The cells were harvested after different lengths of chase, and their labeled proteins were resolved by two-dimensional gel electrophoresis (Fig. 2). After $1 \mathrm{hr}$ of label but no chase, very little label was detected at the position of proteins B1, B2, B3, and B4 (Fig. $2 A$, arrows). There were two prominent, more tightly focused spots, however, at a more basic isoelectric

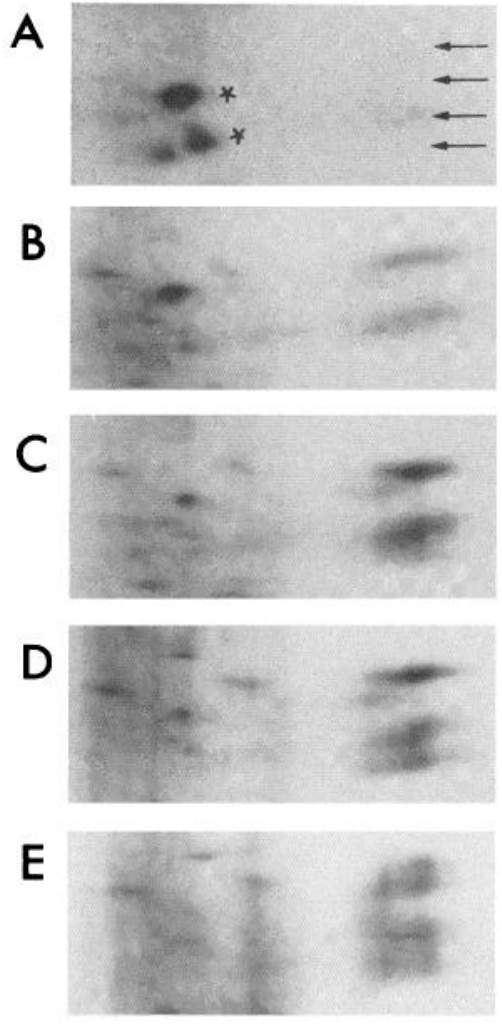

Figure 2. Pulse-chase labeling of B1, B2, B3, and B4 and their precursors. Five matched cultures of superior cervical ganglion neurons were labeled with $\left[{ }^{3} \mathrm{H}\right]$ leucine for $1 \mathrm{hr}$. One culture was harvested at the end of the labeling period, and the others were incubated in medium containing unlabeled leucine for various lengths of time. Proteins were resolved by twodimensional gel electrophoresis as in Figure 1; only the relevant portion of each gel is shown. $A$, One hour of label, no chase; $B$, $1 \mathrm{hr}$ of chase; $C, 2 \mathrm{hr}$ of chase; $D, 4 \mathrm{hr}$ of chase; $E, 7 \mathrm{hr}$ of chase. $\mathrm{P} 1$ and $\mathrm{P} 3$, the precursors of $\mathrm{B} 1$ and $\mathrm{B} 3$, are marked with asterisks in $A$, and $\mathrm{B} 1, \mathrm{~B} 2, \mathrm{~B} 3$, and $\mathrm{B} 4$ are marked with arrows. The gels were of $6 \%$ acrylamide.

point and at slightly lower apparent molecular weights, P1 $\left(M_{\mathrm{r}} \sim 210,000\right)$ and P3 $\left(M_{\mathrm{r}} \sim 185,000\right.$ (Fig. $2 A$, asterisks). After $1 \mathrm{hr}$ of chase, label was seen in proteins $\mathrm{B} 1$ and B3, and very faintly in proteins B2 and B4. After 2 and $4 \mathrm{hr}$ of chase, the proportion of label in proteins $\mathrm{B} 2$ and B4 increased, until after $7 \mathrm{hr}$ of chase, there was more label in proteins B2 and B4 than in proteins B1 and $\mathrm{B} 3$. The label in P1 and P3 declined rapidly in the first $2 \mathrm{hr}$ of chase. The pattern is what one would predict if proteins $\mathrm{B} 1$ and $\mathrm{B} 3$ were derived from non-sialylated (and hence more basic) precursors (P1 and P3), and proteins $\mathrm{B} 2$ and $\mathrm{B} 4$ were derived from proteins $\mathrm{B} 1$ and B3.

Both monoclonal antibody ASCS4 and polyclonal antiserum to NILE precipitated P1 but not P3 (Fig. 3). In this experiment the cells were labeled with $\left[{ }^{35} \mathrm{~S}\right]$ methionine for $1 \mathrm{hr}$.

The glycosylation of the proteins was assessed by repeating the pulse-chase with labeled sugars instead of labeled leucine (Fig. 4). When $\left[{ }^{3} \mathrm{H}\right]$ mannose was used to label the cultures for $1 \mathrm{hr}$, and then chased with medium containing $100 \mu \mathrm{M}$ unlabeled mannose, P1 and P3 were 
A

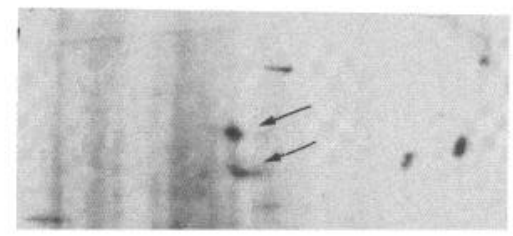

B

Figure 3. Antibody precipitation of the precursor protein, P1. Neuronal cultures were labeled for $1 \mathrm{hr}$ with $\left[{ }^{35} \mathrm{~S}\right]$ methionine, and an NP-40 extract was prepared as in Figure 1. The relevant portion of the two-dimensional gel of an aliquot of the extract is shown in gel $A$; as in Figure 2, there is prominent labeling of P1 and P3 (arrows) and barely detectable labeling of B1 and B3 after $1 \mathrm{hr}$. P1 was precipitated by both the polyclonal antiserum and the monoclonal antibody $(B$, arrow), although the polyclonal antiserum was quantitatively more effective. Gel $B$ shows the precipitate obtained with the polyclonal antiserum. The gels were of $6 \%$ acrylamide.
A

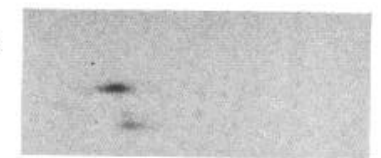

B

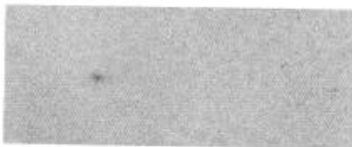

C

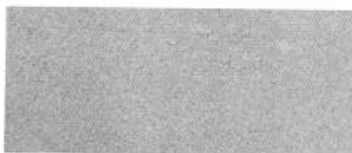

D

E

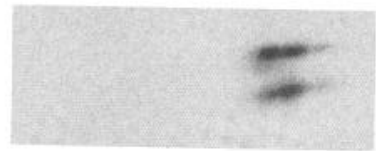

F

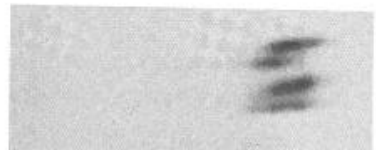

Figure 4. Carbohydrate labeling of B1, B2, B3, and B4 and their precursors. Matched cultures of neurons were labeled for $1 \mathrm{hr}$ with $\left[{ }^{3} \mathrm{H}\right]$ mannose or fucose, and were harvested immediately or incubated with unlabeled mannose or fucose for a further period. $A$, One hour of label with $\left[{ }^{3} \mathrm{H}\right]$ mannose; $B, 1 \mathrm{hr}$ of $\left[{ }^{3} \mathrm{H}\right]$ mannose, $1 \mathrm{hr}$ of chase; $C, 1 \mathrm{hr}$ of $\left[{ }^{3} \mathrm{H}\right]$ mannose, $3 \mathrm{hr}$ of chase; $D, 1 \mathrm{hr}$ of label with $\left[{ }^{3} \mathrm{H}\right]$ fucose; $E, 1 \mathrm{hr}$ of $\left[{ }^{3} \mathrm{H}\right]$ fucose, 1 hr of chase; $F, 1 \mathrm{hr}$ of $\left[{ }^{3} \mathrm{H}\right]$ fucose, $3 \mathrm{hr}$ of chase. The gels were of $6 \%$ acrylamide.

labeled after $1 \mathrm{hr}$, and their label declined rapidly during the chase (Fig. 4, $A$ to $C$ ). When $\left[{ }^{3} \mathrm{H}\right]$ fucose was used instead, no label was detected in P1 or P3. Very little label was detected in proteins B1, B2, B3, and B4 immediately after the labeling period, but B1 and B3 were labeled after $1 \mathrm{hr}$ of chase, and all four were labeled after $3 \mathrm{hr}$ of chase (Fig. $4, D$ to $F$ ). The delay in the incorporation of $\left[{ }^{3} \mathrm{H}\right]$ fucose is puzzling but reproducible, and suggests that the isotope does not equilibrate instantly with intracellular pools. The data are nonetheless consistent with what is known about the processing of glycoproteins in other types of cells (Hubbard and Ivatt, 1981): high mannose, asparagine-linked glycosylated forms of the proteins are detected within an hour of their synthesis; most of the mannose is then removed; and mature, complex glycosylation (including the addition of fucose and sialic acid) occurs subsequently. The mature proteins (B1 and B3) are later modified to forms that have an apparent lower molecular weight by gel electrophoresis (B2 and B4). Consistent with this scheme, P1 and P3 are not detected by cell surface labeling techniques, such as lactoperoxidase-catalyzed iodination (see Fig. 7, below).

The culture medium was also examined during the pulse-chase experiments. No bands resembling proteins B1, B2, B3, and B4 could be detected after gel electrophoresis of the medium, although the unrelated, previously described spontaneously secreted proteins (Sweadner, 1981) were found. This corroborates the previous observation that proteins $\mathrm{B} 1, \mathrm{~B} 2, \mathrm{~B} 3$, and $\mathrm{B} 4$ are not among the proteins released from unstimulated cells (Sweadner, 1981).

Release of protein follows transmitter release. The release of proteins from sympathetic neurons treated with black widow spider venom was previously demonstrated (Sweadner, 1981). Figure 7 of that paper shows a twodimensional gel of the proteins released from $\left[{ }^{3} \mathrm{H}\right]$ leucine-labeled neurons. Three major spots are seen, and two others can be detected after a longer period of autoradiography. Figure 5 of the present paper shows the same family of proteins resolved on one-dimensional gels and illustrates some characteristics of their release. The proteins shown were released from two sister cultures, one noradrenergic and the other cholinergic in phenotype. Each culture was first labeled with $\left[{ }^{3} \mathrm{H}\right]$ leucine overnight, and the first slot shows the pattern of labeled proteins which were spontaneously secreted during the overnight incubation. The second slot shows the proteins released when the cultures were washed and then incubated for $30 \mathrm{~min}$ in a minimal salts solution; a low level of release of the most abundant secreted protein continued in the noradrenergic culture, and nothing was detected in the medium of the cholinergic culture. The next three slots show the protein released in three successive 30 -min treatments with black widow spider venom. Three major and two minor components were released from both noradrenergic and cholinergic cultures. It is characteristic that the ratios of the various components are not fixed; their proportions differed from culture to culture and from sample to sample from the same culture. The major components had apparent $M_{\mathrm{r}}$ of $\sim 215,000$, 185,000 , and 125,000. The two largest are marked with arrows (Fig. 5B) and are called S2 and S4, as justified below. The smaller components may be proteolytic fragments of the larger ones, but they have not yet been characterized. Protein release was usually complete within $2 \mathrm{hr}$.

Several experiments indicate that the released proteins are glycoproteins and that they are derived not from synaptic vesicles, but from the cell surface. They can be labeled or modified by treatment of intact cells with enzymes that presumably have no access to the interior of the cell. Figure $6, A$ to $C$, shows first that the released proteins (labeled with $\left[{ }^{3} \mathrm{H}\right]$ leucine) contain sialic acid, as indicated by the fact that their isoelectric focusing point 
A

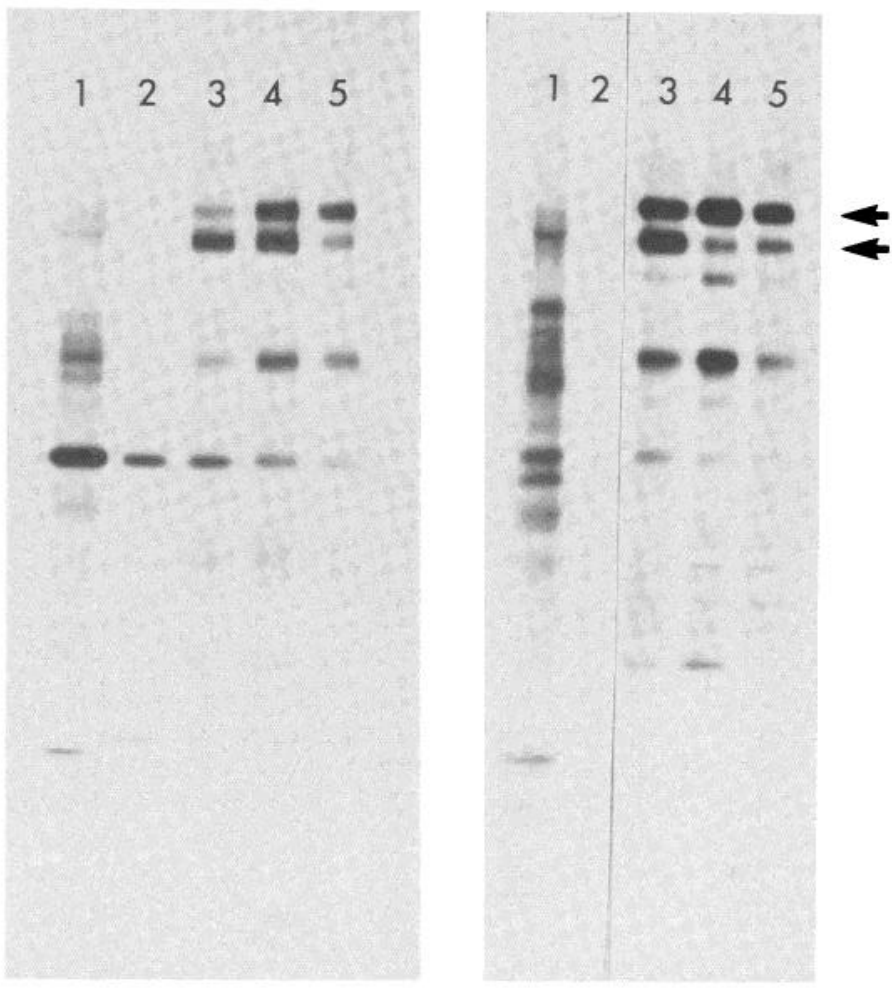

Figure 5. Protein release elicited with black widow spider venom. $A$ and $B$ show the different kinds of proteins released into the medium from $(A)$ noradrenergic and $(B)$ cholinergic sympathetic neurons. Cultures were labeled with $\left[{ }^{3} \mathrm{H}\right]$ leucine overnight, and slots 1 show the pattern of proteins that are labeled and spontaneously released during the incubation with the isotope. Slots 2 show the background release during a 30 min incubation after the labeled leucine has been washed out. Slots 3,4 , and 5 show successive 30 -min incubations with black widow spider venom. Arrows mark S2 and S4. The crude venom was a homogenate of two spider glands in $100 \mu \mathrm{l}$ of Tris buffer, $\mathrm{pH} 7.2$, and was diluted 1:600 in minimal salts solution. There are no reproducible differences between the proteins released by black widow spider venom from noradrenergic and cholinergic neurons.

was shifted to a more basic position after neuraminidase treatment. Treatment of the released proteins with neuraminidase also reduces their apparent molecular weight on sodium dodecyl sulfate gels. If intact cells are pretreated with neuraminidase, washed extensively, and then treated with black widow spider venom, the released proteins have the lower apparent molecular weights (Fig. 6, $D$ and $E$ ).

Labeled proteins were also released when neurons labeled with $\left[{ }^{3} \mathrm{H}\right]$ fucose were treated with black widow spider venom (Fig. $6 F$ ). No proteins were released from cells that had been enzymatically digested with trypsin prior to evoking transmitter release, however. In Figure $6 G,\left[{ }^{3} \mathrm{H}\right]$ fucose-labeled cells were incubated with $100 \mu \mathrm{g} /$ $\mathrm{ml}$ of crystalline trypsin in minimal salts for $30 \mathrm{~min}$ at $37^{\circ} \mathrm{C}$. The trypsin was removed and the cells were washed with $1 \mathrm{mg} / \mathrm{ml}$ of soybean trypsin inhibitor and subsequently treated with black widow spider venom. No protein release could be detected then, or when pCMBS (see Table I below) was used to elicit transmitter release after trypsinization (not shown), which argues that trypsin does not simply destroy the venom toxin or its receptor. Trypsin treatment does not by itself cause transmitter release (not shown). To test the adequacy of the protease inhibition, unlabeled control cultures were incubated with trypsin and soybean trypsin inhibitor by the same protocol, and then were incubated with an aliquot of labeled released proteins from another culture for $30 \mathrm{~min}$; there was no detectable degradation of the labeled proteins (not shown).

Finally, if cultures were first labeled at $0^{\circ} \mathrm{C}$ by lactoperoxidase-catalyzed iodination of the cell surface and subsequently treated with black widow spider venom at $37^{\circ} \mathrm{C}$ for $45 \mathrm{~min}$, the proteins that were released were labeled. Figure $7 \mathrm{~A}$ shows a two-dimensional gel of the iodinated surface proteins of an untreated culture, and Figure $7 C$ shows the three major and two minor components that were released into the medium. Figure $7 B$ shows the gel of the iodinated proteins that were left behind on the cells after the black widow spider venom treatment; there was depletion of the proteins B1, B2, $\mathrm{B} 3$, and B4.

The comigration of the released proteins and proteins B1, B2, B3, and B4 was tested by two-dimensional gel electrophoresis. Sister cultures were labeled with $\left[{ }^{3} \mathrm{H}\right]$ fucose, and one was treated with black widow spider venom for $45 \mathrm{~min}$. Figure $8 \mathrm{~A}$ shows the relevant portion of a two-dimensional gel of the untreated culture; $\mathrm{B} 1$, B2, B3, and B4 are marked with arrows. In Figure $8 B$, the gel of the sister culture is seen after treatment with the venom; there appears to be a reduction in B1 and B3 and an increase in B2 and B4. In Figure $8 C$, the proteins released into the medium are shown, and in Figure $8 D$, the released proteins were mixed with an aliquot of the extract used for Figure $8 \mathrm{~A}$. The two highest molecular weights of the released proteins (large arrows) comigrated with B2 and B4. Since these appear to be a soluble form of B2 and B4, they are called S2 and S4. The amounts of B2, B4, S2, and S4 appear to increase at the expense of B1 and B3. The other, lower molecular weight released proteins do not overlap with any other obvious surface proteins.

Both the monoclonal antibody ASCS4 and the antiNILE antiserum which precipitate B1 and B2 (Fig. $1 B$ ) were also found to precipitate $\mathrm{S} 2$, and neither precipitated S4 or the other released proteins; Figure 9 shows the precipitate obtained with the polyclonal antiserum, which was quantitatively better than that of the monoclonal antibody. This confirms the relationship of the cell surface-associated B1 and B2 and the larger of the released proteins, S2.

Calcium dependence of protein release. The active ingredient in black widow spider venom that elicits transmitter release by the exocytosis of synaptic vesicles is the protein toxin $\alpha$-latrotoxin, but the crude venom also contains hydrolytic enzymes (Howard and Gunderson, 1980). To determine whether the release of protein is a consequence of the release of transmitter or of the presence of some other activity in the venom, and to determine whether the release of transmitter is invariably accompanied by the release of protein, a variety of other, 


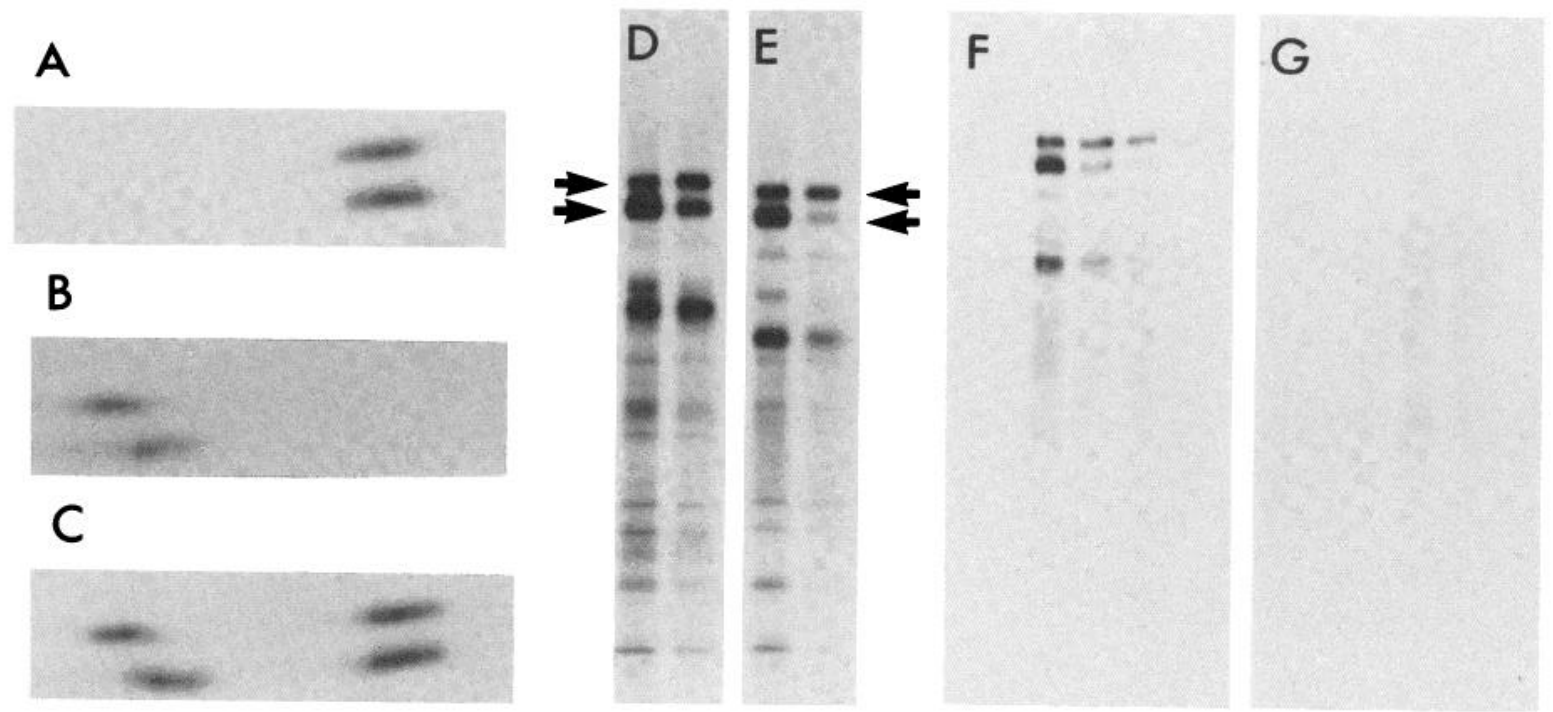

Figure 6. The released proteins are glycoproteins. $A, B$, and $C$ show portions of two-dimensional gels, illustrating the shift in isoelectric point of $\mathrm{S} 2$ and $\mathrm{S} 4$ when treated with neuraminidase. $A, \mathrm{~S} 2$ and $\mathrm{S} 4$ before neuraminidase treatment; $C, \mathrm{~S} 2$ and $\mathrm{S} 4$ after neuraminidase treatment; $B$, aliquots of the samples used in $A$ and $C$ were mixed after denaturation in sodium dodecyl sulfate and electrophoresed on the same gel. $D$ and $E$ show the shift in apparent molecular weight of S2 and S4 (arrows) released from cells that were not $(D)$ or were $(E)$ treated with neuraminidase after overnight labeling with [ $\left.{ }^{3} \mathrm{H}\right]$ leucine, but before treatment with black widow spider venom. $F$ shows S2 and S4 released by treatment with black widow spider venom after labeling with $\left[{ }^{3} \mathrm{H}\right]$ fucose, and $G$ shows that no proteins are released from a culture labeled the same way, but treated with trypsin, followed by soybean trypsin inhibitor, before black widow spider venom. $F$ and $G$ were from a gel electrophoresed on a different day from that of panels $D$ and $E$; the apparent difference in mobility has no significance.

unrelated agents which cause transmitter release was tried. Their ability to cause protein release was assessed by the experimental protocol used in Figure 5, and their ability to elicit transmitter release was assessed by measuring the rate of release of $\left[{ }^{3} \mathrm{H}\right]$ norepinephrine. The results are shown in Table I. Depolarizing the neurons with $54 \mathrm{mM} \mathrm{K}^{+}$accelerated transmitter release (Patterson et al., 1976), but not as much as black widow spider venom, and it did not elicit detectable release of the proteins, the first indication that the two events may be separable. Substituting $\mathrm{Ba}^{2+}$ for $\mathrm{Ca}^{2+}$ in the presence of $54 \mathrm{~mm} \mathrm{~K}{ }^{+}$caused much higher rates of transmitter release (as reported by Douglas et al., 1961), and in this case protein release was detected. Veratridine, a toxin which depolarizes the cell by opening the voltage-sensitive $\mathrm{Na}^{+}$channel (Ohta et al., 1973), also caused a rapid release of transmitter and elicited the release of the proteins. Both effects of veratridine were blocked by tetrodotoxin, which antagonizes veratridine by blocking the voltage-sensitive $\mathrm{Na}$ channel. A23187, which is an ionophore with a high selectivity for $\mathrm{Ca}^{2+}$ (Pressman, $1976)$, caused both transmitter release and protein release, and both of these effects were blocked by $\mathrm{Co}^{2+}$, a $\mathrm{Ca}^{2+}$ antagonist.

Black widow spider venom, $54 \mathrm{mM} \mathrm{K}^{+}$plus $\mathrm{Ba}^{2+}$, veratridine, and A23187 are all believed to elicit transmitter release through normal cellular mechanisms but by bypassing normal control mechanisms. Three other reagents were tried which can elicit transmitter release by making the cell nonspecifically leaky or by acting as ionophores: pCMBS, which has been used to permeabilize a variety of cells and which has been used previously to evoke transmitter release (Carmody, 1978; Baba et al.,
1979), alamethicin, a channel-forming ionophore with a very low selectivity (Pressman, 1976), and monensin, an ionophore that exchanges $\mathrm{Na}^{+}$for $\mathrm{H}^{+}$or $\mathrm{K}^{+}$(Charlton et al., 1980; Meiri et al., 1981). All three of these reagents caused rapid release of transmitter, release of protein, and later, cell lysis (Table I). Exposing the cultures to air during repeated washes, or other physical trauma, can also result in transmitter and protein release.

The conditions used to evoke transmitter and protein release were unquestionably harsh, but protein release was highly selective; other cell surface proteins were not reproducibly affected. Even when a reagent such as alamethicin was used, which causes cell lysis within hours, the release of transmitter and proteins preceded the cell lysis in time (data not shown).

The release of proteins appears to always require the presence of $\mathrm{Ca}^{2+}$ in the extracellular medium. In the absence of added $\mathrm{Ca}^{2+}$, no protein release was seen when neurons were treated with black widow spider venom, pCMBS, or A23187. Addition of $\mathrm{Ca}^{2+}$ after $1 \mathrm{hr}$ of venom or pCMBS treatment resulted in the delayed release of protein. The $\mathrm{Ca}^{2+}$ antagonist $\mathrm{Co}^{2+}$ at $2 \mathrm{mM}$ blocked the release of protein elicited by black widow spider venom, high $\mathrm{K}^{+}$plus $\mathrm{Ba}^{2+}$, and $\mathrm{A} 23187$, but did not completely block that elicited by pCMBS. $\mathrm{La}^{3+}$, which acts as a $\mathrm{Ca}^{2+}$ antagonist or agonist in different systems, blocked protein release at $5 \mathrm{~mm}$ under all conditions, even pCMBS. The results obtained with the black widow spider venom are representative, and are shown in Figure 10.

When $\left[{ }^{3} \mathrm{H}\right]$ leucine-labeled cells were used to elicit protein release and the proteins left bound to the cells were examined by two-dimensional gel electrophoresis, the precursors of the released proteins could be examined. 


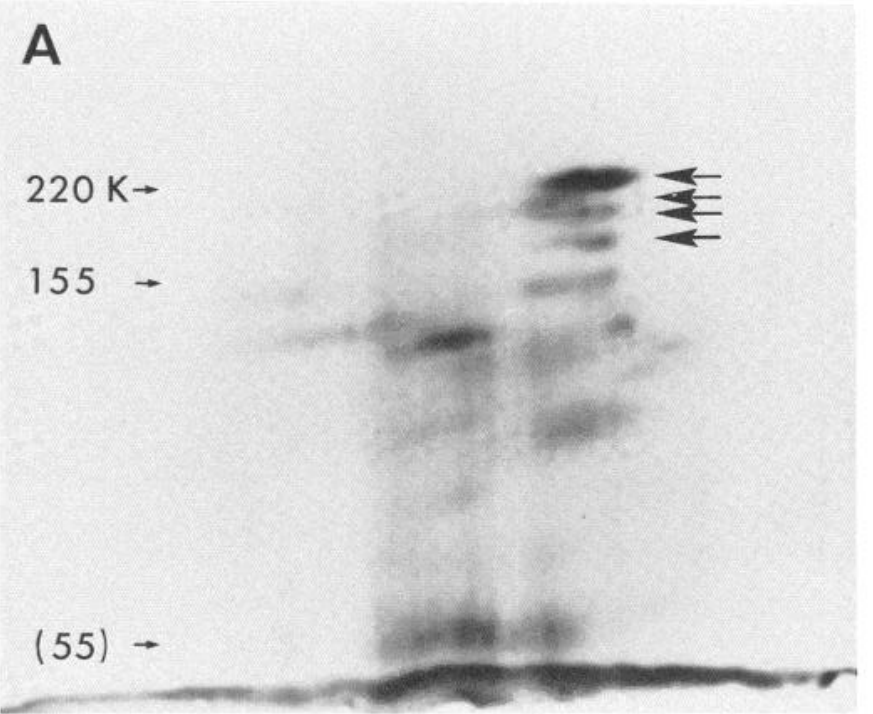

B

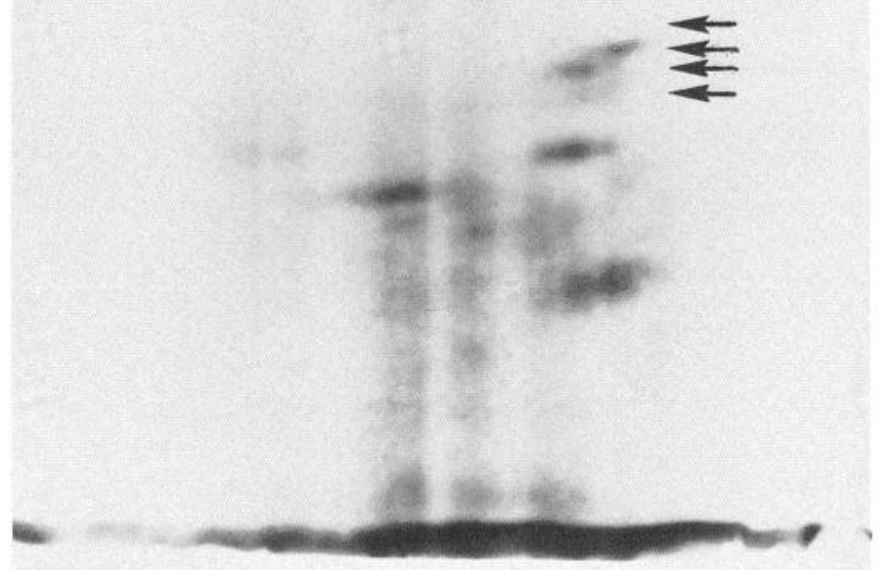

C

Figure 7. The released proteins derive from iodinatable cell surface proteins. Cultures were labeled by lactoperoxidasecatalyzed iodination at $0^{\circ} \mathrm{C}$. $A$, Labeled surface proteins from control cells; B1, B2, B3, and B4 are marked with large arrows,
In Figure 11 $A$, cell surface proteins B1, B2, B3, and B4 are seen in a section of a two-dimensional gel of untreated neurons. In Figure $11 B$, a sister culture was treated for $1.5 \mathrm{hr}$ with black widow spider venom in the presence of $\mathrm{Ca}^{2+}$; proteins $\mathrm{B} 1$ to $\mathrm{B} 4$ were completely depleted. In Figure $11 C$, a sister culture was treated with black widow spider venom in the absence of $\mathrm{Ca}^{2+}$; proteins $\mathrm{B} 1$ to $\mathrm{B} 4$ appeared similar to the control. These same four proteins were absent after the cells were treated with trypsin as in Figure 6 (Fig. 11D).

A functional separation of transmitter and protein release could be obtained because transmitter release does not always require exogenous $\mathrm{Ca}^{2+}$, even when protein release does. Black widow spider venom, pCMBS, and A23187 were all capable of eliciting transmitter release in the absence of added $\mathrm{Ca}^{2+}$ in the medium (Fig. $12, A$ to $C$ ). This has been reported before for black widow spider venom (Baba and Cooper, 1980) and pCMBS (Baba et al., 1979). The effect of A23187 is probably due to its ability to penetrate to intracellular membranes, where it could release $\mathrm{Ca}^{2+}$ from intracellular stores. An even more compelling effect was that of $\mathrm{La}^{3+}$, which acted as a $\mathrm{Ca}^{2+}$ agonist for transmitter release and, in fact, elicited it by itself (Fig. $12 D$; Weiss, 1974). Not only did it not cause protein release, but it actually inhibited the protein release elicited by black widow spider venom. It did not block venom-induced norepinephrine release, but it was reproducibly found to reduce it relative to the rate seen in its absence (Fig. $12 D)$.

Attempts to determine the mechanism of protein release. In Figure 8, it appears that the treatment with black widow spider venom accelerated the conversion of $\mathrm{B} 1$ and $\mathrm{B} 3$ to $\mathrm{B} 2$ and B4. If the mechanism of protein release is to somehow accelerate the normal metabolism of this family of proteins, then one might predict that labeling the cells in the absence of $\mathrm{Ca}^{2+}$ in the medium would block the spontaneous conversion of $\mathrm{B} 1$ and $\mathrm{B} 3$ to $\mathrm{B} 2$ and $\mathrm{B} 4$, and that labeling in high $\mathrm{K}^{+}$would accelerate the conversion. Experimental results do not support this hypothesis, however (data not shown). Cultures labeled with $\left[{ }^{3} \mathrm{H}\right]$ fucose in the absence of added $\mathrm{Ca}^{2+}$ or in the presence of $20 \mathrm{~mm}$ or $54 \mathrm{mM} \mathrm{K}^{+}$have B1 to B4 patterns identical to those of controls. It appears that transmitter release and the presence of extracellular $\mathrm{Ca}^{2+}$ are required only for the conversion of B2 and B4 to S2 and S4.

The varying proportions of the released proteins are what one might expect of a process that involves a stochastic event like limited proteolysis, and a number of attempts have been made to find a protease inhibitor

and the molecular weights of several proteins are shown on the left. The protein marked $M_{r}-55,000$ is the protein C55 described in Braun et al. (1981), which migrates anomalously. The gels are of $5 \%$ acrylamide. $B$, Surface proteins after black widow spider venom treatment; B1 is essentially entirely lost. $C$, Proteins released by black widow spider venom. S2 and S4 are marked with arrows. The extent of labeling of minor released components is more variable than that of the major ones; in this experiment, the most basic component is more heavily labeled than usual. 

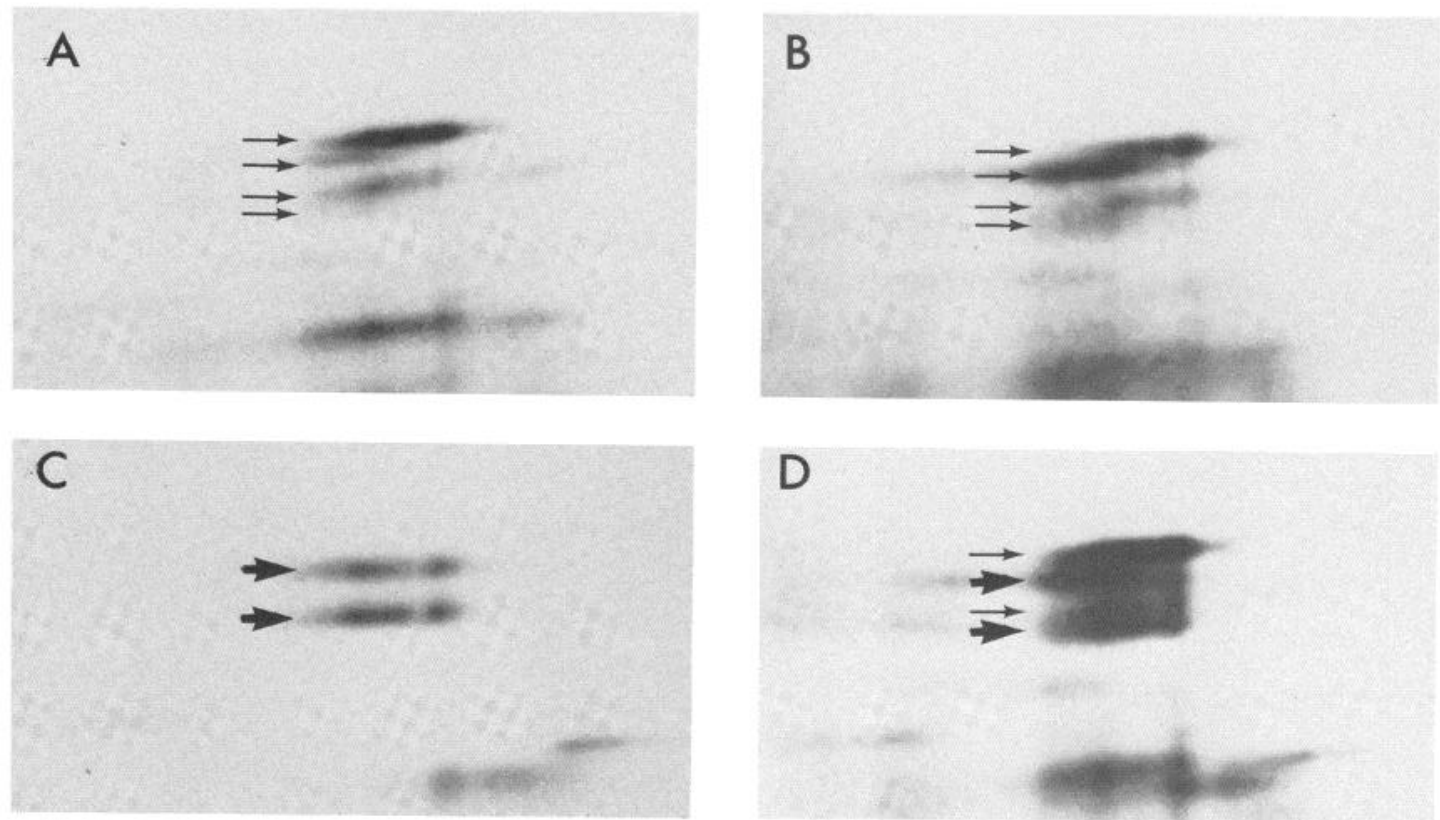

Figure 8. The released proteins comigrate with $\mathrm{B} 2$ and $\mathrm{B} 4$. Cultures were labeled with $\left[{ }^{3} \mathrm{H}\right]$ fucose overnight. A, Labeled proteins of a control culture: $\mathrm{B} 1, \mathrm{~B} 2, \mathrm{~B} 3$, and $\mathrm{B} 4$ are marked with arrows. $B$, Labeled proteins of a culture treated with black widow spider venom. B2 and B4 appear to be increased relative to $\mathrm{B} 1$ and $\mathrm{B} 3$. $C$, Labeled proteins released into the medium by black widow spider venom. S2 and $\mathrm{S} 4$ are marked with arrows. $D$, Aliquots of the samples used in gels $A$ and $C$ were mixed and electrophoresed on the same gel. B1 and B3 are marked with small arrows, and S2 and S4 are marked with large arrows.
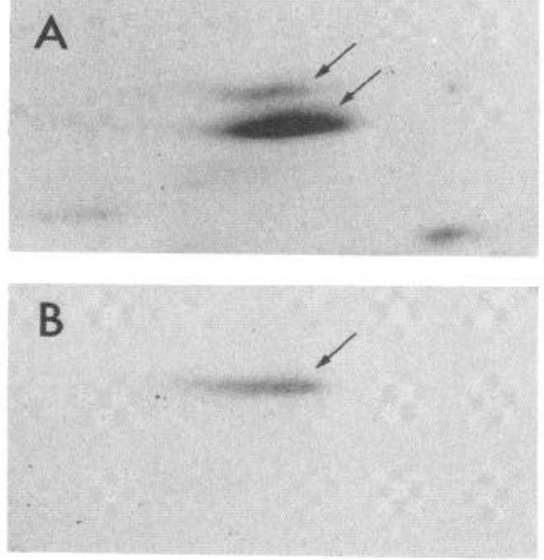

Figure $9 . \mathrm{S} 2$ is precipitated by antibodies against $\mathrm{B} 1$ and $\mathrm{B} 2$. $A$, Cultures were labeled with $\left[{ }^{35} \mathrm{~S}\right]$ methionine overnight, and protein release was evoked with pCMBS. S2 and S4 are marked with arrows. $B$, Immunoprecipitate of the proteins shown in gel $A$, using the polyclonal antiserum against NILE. Only $\mathrm{S} 2$ was precipitated.

that will block the release of protein. All of the following inhibitors were without effect, however: phenylmethylsulfonyl fluoride $(0.1 \%)$; chloroquine $(50 \mu \mathrm{M})$; leupeptin $(100 \mu \mathrm{M})$; pepstatin $(25 \mu \mathrm{M})$; chymostatin $(25 \mu \mathrm{M})$; Ep475 $(100 \mu \mathrm{M})$; aprotinin $(100 \mu \mathrm{g} / \mathrm{ml})$; and diisopropyl fluorophosphate $(10 \mu \mathrm{M})$. All of the protease inhibitors were preincubated with the labeled cultures for $30 \mathrm{~min}$ prior to treatment with black widow spider venom. These compounds should inhibit a wide range of proteases: extracellular, lysosomal, and cytoplasmic.
Experiments were also performed to test the hypothesis that an unknown protease or other enzymatic activity is secreted into the medium when transmitter release is evoked. pCMBS was used to evoked transmitter release from an unlabeled culture, the supernatant was collected, and the pCMBS in it was inactivated with excess $\beta$ mercaptoethanol. The supernatant, which should contain any soluble proteases released by the unlabeled culture, was then put onto a labeled culture and incubated for three 30 -min periods. For controls, one labeled culture was incubated with pCMBS as usual, and another was incubated with pCMBS that had first been inactivated with excess $\beta$-mercaptoethanol. Finally, a culture was treated with black widow spider venom in the presence of $\beta$-mercaptoethanol, which showed that the reducing agent by itself has no effect on protein release. The result was that the transferred supernatant caused little or no specific release of protein (not shown), and thus does not contain significant released or activated protease.

\section{Discussion}

The identity of the proteins. This paper provides evidence that two cell surface proteins of sympathetic neurons undergo sequential processing: $\mathrm{P} 1 \rightarrow \mathrm{B} 1 \rightarrow \mathrm{B} 2 \rightarrow$ $\mathrm{S} 2$, and $\mathrm{P} 3 \rightarrow \mathrm{B} 3 \rightarrow \mathrm{B} 4 \rightarrow \mathrm{S} 4$. Proteins $\mathrm{B} 1, \mathrm{~B} 2, \mathrm{~B} 3$, and $\mathrm{B} 4$ are among the most abundant surface proteins when labeled either by cell surface probes or by the metabolic incorporation of labeled fucose (Braun et al., 1981). Their accessibility to lactoperoxidase, galactose oxidase, neuraminidase, and trypsin in intact cells argues that they are exposed on the cell surface. The fact that they can 
TABLE I

Chemically evoked release of norepinephrine and surface proteins

The rate of $\left[{ }^{3} \mathrm{H}\right]$ norepinephrine (NE) release, expressed as percentage of stored transmitter released per hour, is given for representative experiments in the presence and absence of calcium. Release of surface protein (S2 and S4) was scored as strong $(++)$, weak $(+)$, or negative $(0)$, and the number of separate experiments in which each result was found is given in parentheses. Blanks indicate that the experiment was not done. Conditions used were: black widow spider venom (BWSV), 1:600 dilution of venom extract; $54 \mathrm{mM} \mathrm{K}^{+} ; 54 \mathrm{mM} \mathrm{K}^{+}$plus $10 \mathrm{mM} \mathrm{BaCl}_{2}$; $\mathrm{LaCl}_{3}, 5 \mathrm{mM}$; veratridine, $5 \times 10^{-5} \mathrm{M}$; tetrodotoxin (TTX), $10^{-5} \mathrm{M}$; A23187, $10^{-5} \mathrm{M} ; \mathrm{p}$-chloromercuribenzene sulfonate (pCMBS), $10^{-4} \mathrm{M}$; alamethicin, $10^{-5} \mathrm{M}$; monensin, $10^{-5} \mathrm{M} ; \mathrm{CoCl}_{2}, 2 \mathrm{~mm}$.

\begin{tabular}{|c|c|c|c|c|c|c|}
\hline & \multicolumn{2}{|c|}{ NE Release } & \multicolumn{4}{|c|}{ Protein Release } \\
\hline & $+\mathrm{Ca}^{2+}$ & $-\mathrm{Ca}^{2+}$ & $+\mathrm{Ca}^{2+}$ & $-\mathrm{Ca}^{2+}$ & $+\mathrm{Co}^{2+}$ & $+\mathrm{La}^{3+}$ \\
\hline Control & 12.0 & 12.5 & $0(11)$ & $0(2)$ & & \\
\hline $54 \mathrm{mM} \mathrm{K}^{+}$ & 27.5 & 13.0 & $+(1) ; 0(12)$ & $0(2)$ & $0(1)$ & $0(1)$ \\
\hline $54 \mathrm{mM} \mathrm{K}^{+}+\mathrm{Ba}^{2+}$ & 44.0 & & $++(5) ; 0(4)$ & & $0(2)$ & \\
\hline $\mathrm{La}^{3+}$ & 47.0 & & $0(4)$ & $0(1)$ & $0(1)$ & \\
\hline A23187 & 43.0 & & $++(5)$ & $0(1)$ & $0(1)$ & \\
\hline pCMBS & 93.5 & 90.0 & $++(17)$ & $0(4)$ & $++(2)$ & $0(2)$ \\
\hline Alamethicin & 87.5 & & $++(2)$ & & & \\
\hline Monensin & 88.5 & 82.5 & $++(2)$ & & & \\
\hline
\end{tabular}

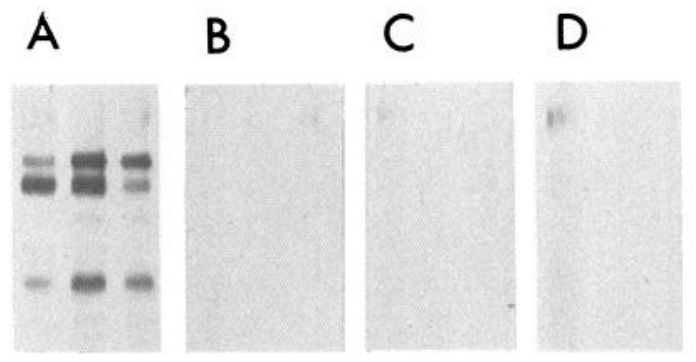

Figure 10. The effect of calcium, cobalt, and lanthanum on release of $\mathrm{S} 2$ and $\mathrm{S} 4 . \mathrm{S} 2, \mathrm{~S} 4$, and lower molecular weight components released from $\left[{ }^{3} \mathrm{H}\right]$ leucine-labeled cultures by black widow spider venom: $A$, in the presence of $1.2 \mathrm{~mm}$ calcium; $B$, in the absence of added calcium; $C$, in the presence of calcium and of $2 \mathrm{mM} \mathrm{CoCl}_{2} ; D$, in the presence of calcium and of $5 \mathrm{mM}$ $\mathrm{LaCl}_{3}$. When cobalt and lanthanum were used, EDTA was added to the samples prior to preparation for gel electrophoresis because the cations formed an insoluble precipitate with the electrophoresis sample buffer.

be released in soluble form argues that they do not bury the bulk of their mass in the lipid bilayer, although they may be anchored to it by a hydrophobic tail that can be clipped off. There is no evidence for an internal pool of the releasable proteins, protected from external enzymatic modification, although the low time resolution of the experiments ( $30 \mathrm{~min}$ ) would have precluded detection of a pool that shuttles rapidly in and out of the cell. It is striking that such major, externally directed proteins can be essentially entirely released from the cells following chemically evoked transmitter release.

$\mathrm{B} 1$ and $\mathrm{B} 2$ cross-react with the nerve growth factorinducible NILE protein of PC12 cells (McGuire et al., 1978), but no evidence was obtained for an antigenic relationship between B1-B2 and B3-B4, despite their similar behavior. Salton et al. (1983) and Stallcup et al. (1983) both found that antisera that precipitate NILE will precipitate related proteins of slightly different molecular weights from different neuronal sources, including the central nervous system. Two-dimensional gel analysis might reveal the presence of multiple bands in these precipitates, as seen here. The accompanying paper (Sweadner, 1983), however, presents evidence that the apparent molecular weights determined by electrophoresis in sodium dodecyl sulfate are very inaccurate.

In their high molecular weight and releasability, B1, B2, B3, and B4 resemble the cell surface proteins described on several other kinds of cells of neural origin. The NS- 4 and BSP- 2 antigens of mouse brain and the $\mathrm{N}$-CAM (neural cell adhesion molecule) protein and D2 antigen of chick and rat brain all have components of $M_{\mathrm{r}} \sim 180,000$ to $200,000,140,000$, and 120,000 , which are sialic acid- and fucose-containing glycoproteins expressed on the cell surface, and which are shed into the medium (Thiery et al., 1977; Jorgensen et al., 1980; Rohrer and Schachner, 1980; Hirn et al., 1981; Chuong et al., 1982). Very similar major neuronal cell surface proteins have been described in other laboratories as well (Akeson and Hsu, 1978; Littauer et al. 1980; Chen and Rinehart, 1982), so similar that perhaps they are all the same family of proteins. Both the NS-4 antigen and the $\mathrm{N}$-CAM protein are found as higher molecular weight forms in cells of embryonic origin (Goridis et al., 1978; Rothbard et al., 1982); biochemical analysis of the embryonic and adult forms has revealed that they differ chiefly in their carbohydrate structures (Rothbard et al., 1982). At this time, we do not know whether the NILErelated family of proteins is the same as the NS-4, BSP2 , and N-CAM family. Proteins of $M_{\mathrm{r}}=230,000,180,000$, and 140,000 were all detected by complex antisera against PC12 cells by Lee et al. (1981) and by Stallcup et al. (1983), but cross-adsorbtion experiments suggest that the $M_{\mathrm{r}}=230,000$ component (NILE) is unrelated to the others, which more closely resemble NS-4 and N-CAM.

The conversion of $\mathrm{B} 1$ and $\mathrm{B} 3$ to $\mathrm{B} 2$ and $\mathrm{B} 4$ occurs after the proteins have received their complex carbohydrates, since it occurs after the incorporation of $\left[{ }^{3} \mathrm{H}\right]$ fucose. It also apparently occurs after the insertion of the proteins in the plasma membrane, since all four protein bands are labeled when cultures are iodinated with lactoperoxidase at $0^{\circ} \mathrm{C}$. The conversion bears no 
A

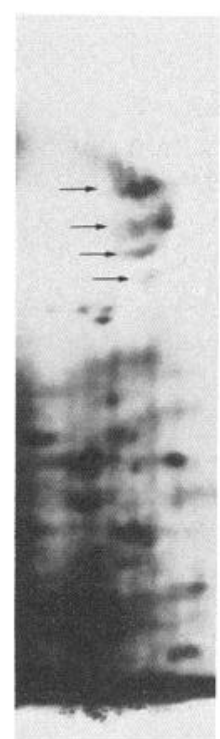

B

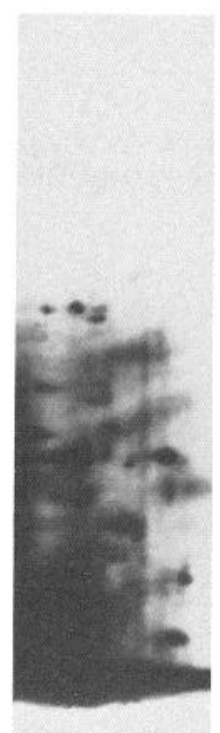

C

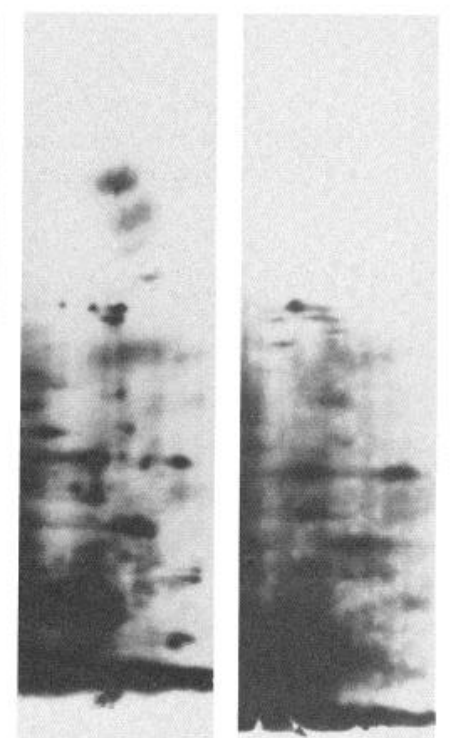

Figure 11. The calcium dependence of the release of $\mathrm{B} 1, \mathrm{~B} 2$, B3, and B4. The acidic portions of two-dimensional gels of $\left[{ }^{3} \mathrm{H}\right]$ leucine-labeled cultures are shown; the gels are of $5 \%$ acrylamide. $A$, Control culture. B1, B2, B3, and B4 are marked with arrows. $B$, After $2 \mathrm{hr}$ of treatment with black widow spider venom, B1, B2, B3, and B4 are almost entirely missing. $C$, After $2 \mathrm{hr}$ of black widow spider venom in the absence of added calcium, B1, B2, B3, and B4 are unaffected. D, Trypsin treatment $\left(100 \mu \mathrm{g} / \mathrm{ml}, 30 \mathrm{~min}\right.$ at $\left.37^{\circ} \mathrm{C}\right)$ degrades B1, B2, B3, and B4.

resemblance to the removal of a signal sequence, which would be expected to occur even before the addition of high mannose carbohydrate units. The conversion could be the result of proteolysis, since there is an apparent drop in molecular weight, but it is also possible that the removal of carbohydrate or covalently linked lipid is responsible for the alteration of electrophoretic mobility.

Release of surface protein. The NILE protein has been reported to be released into the medium, but spontaneously, not in response to the evoked release of neurotransmitter (Salton et al., 1983; Stallcup et al., 1983). It is possible that B1, B2, B3, and B4 are also released spontaneously at low rates, or in response to gentler neuronal stimulation, and yet are undetected here because they are degraded to lower molecular weight fragments before they are collected for analysis by gel electrophoresis. In many experiments the protease inhibitors aprotinin and phenylmethylsulfonyl fluoride were included in all of the solutions, without effect on the results, but that does not rule out that proteases with different specificities are present. Spontaneous protein release was seen in several isolated experiments, but it was the exception rather than the rule. The spontaneous release of a derivative of NILE seen by Salton et al. (1983) and Stallcup et al. (1983) may account for the fact that an equivalent of B2 is not detected in PC12 cells; it may be shed into the medium as soon as it is formed.

The release of NS-4, BSP-2, N-CAM, and other proteins is apparently spontaneous, but there have been no attempts to accelerate the release by evoking transmitter

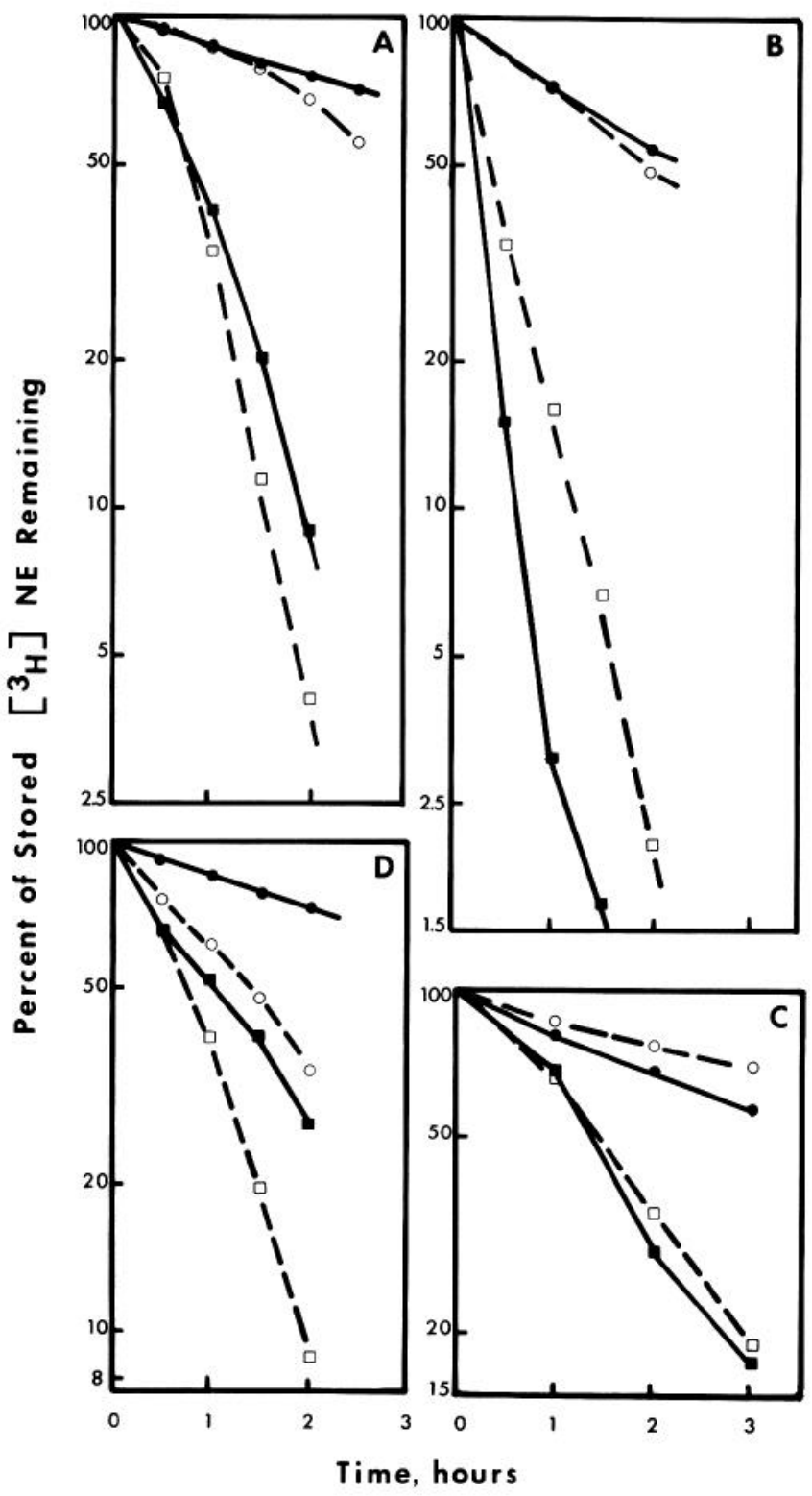

Figure 12. The chemically evoked release of norepinephrine. Cultures were loaded with exogenous $\left[{ }^{3} \mathrm{H}\right]$ norepinephrine, and the release of label into the medium was followed at intervals of $30 \mathrm{~min}$ or $1 \mathrm{hr}$. Data are expressed as the percentage of stored norepinephrine remaining in the cells at each time point. $A$, Black widow spider venom with and without calcium. control; $\mathrm{O}$, control minus calcium; $\mathrm{n}$, black widow spider venom; $\square$, black widow spider venom minus calcium. $B$, pCMBS with and without calcium. - control; $O$, control minus calcium; $\mathbf{\square}$, $0.5 \mathrm{~mm}$ pCMBS; $\square$, pCMBS minus calcium. $C$, A23187 with and without calcium. $\mathrm{O}$, control; $\mathrm{O}$, control minus calcium; $\mathbf{n}$, $10 \mu$ M A23187; $\square$, A23187 minus calcium. D, Lanthanum with and without black widow spider venom. control; $\bigcirc, 5 \mathrm{~mm}$ lanthanum; $\square$, black widow spider venom; $\mathbf{\square}$, black widow spider venom plus $5 \mathrm{~mm}$ lanthanum.

release, or to determine whether the release requires extracellular calcium. Musick (1979) observed the release of protein from stimulated neuromuscular preparations and found that the amount of protein released exceeded the estimated content of the synaptic vesicles. He concluded that the source of the protein could not be solely 
the synaptic vesicles. It is possible that the protein came from the neuronal cell surface, as described here, or from the muscle. The shedding of cell adhesion molecules such as N-CAM can be understood in the context of cell migration in relation to its environment, but the shedding of cell surface proteins during or after neurotransmitter release remains an unexplained observation.

Mechanism of protein release. There is biochemical evidence that certain proteins, the chromogranins and dopamine $\beta$-hydroxylase, are released from adrenal medullary chromaffin granules when they release catecholamines by exocytosis (Schneider et al., 1967), and there is immunological evidence that similar proteins are released from noradrenergic neurons (Smith et al., 1970). Labeled sympathetic neurons were treated with black widow spider venom to determine whether the neurotransmitter-specific secreted proteins (A82, C76, C111, and $\mathrm{C} 145$ ) were derived from synaptic vesicles, and it was found that there was a separate class of releasable proteins unrelated to the spontaneously secreted proteins (Sweadner, 1981). In this paper, these releasable proteins (S2, S4, and presumed fragments) have been shown to be derived from the surface proteins B1, B2, B3, and B4. The induced release of protein is selective, in that it does not reproducibly affect the other most abundant cell surface proteins.

Since the mechanism of release could offer a clue to the function of the proteins, it has been studied in some detail. Classically, proteins destined for secretion are packaged in the cell and secreted without being exposed on the cell surface. In some cases, a cell both secretes a protein and exposes it on the cell surface, and it does this either by producing two separate forms of the protein, or by modifying a membrane-bound form to permit its release. Some muscle acetylcholine esterase forms are found in a rapidly turning-over intracellular pool and are secreted directly to the medium, and others are inserted in the membrane and remain there with a half-life of 50 hr (Rotundo and Fambrough, 1980). Immunoglobulins are also made in membrane-bound and secreted forms, which have identical $\mathrm{N}$-termini and different $\mathrm{C}$-termini (Cushley et al., 1982). Other proteins appear to be shed from the cell surface, since they can be labeled on the cell surface and later found in the medium in a labeled, soluble form, as reported here. Since this has been observed for high molecular weight proteins from a variety of cells of neural origin (Thiery et al., 1977; Akeson and $\mathrm{Hsu}, 1978$; Goridis et al., 1980), it will be of interest to determine its physiological role.

The simplest hypothesis is that the proteins are released from the surface by limited proteolysis. If the proteins are anchored to the membrane by a short, terminal hydrophobic stretch of amino acids, cleaving the polypeptide chain near that stretch would release a nearly intact soluble fragment. The release could be the work of a calcium-dependent protease or of a proteolytic process that is activated indirectly by calcium (Baudry et al., 1981; Rodemann et al., 1982). In polymorphonuclear leukocytes there is even an evoked, calcium-dependent release of lysosomal proteases into the extracellular medium (Showell et al., 1977). No protease inhibitors have yet been found that inhibit the release of S2 and $\mathbf{S} 4$, however.
Release of S2 and S4 occurs in conditions that elicit rapid neurotransmitter release. A comparison of the ionic requirements for protein release and transmitter release leads to the conclusion that the two events are separable, since protein release requires extracellular calcium even when transmitter release does not, as with black widow spider venom and pCMBS. Since transmitter release can occur without protein release but the converse is not true, the protein release correlates better with events following transmitter release; for instance, the recapture of synaptic vesicle membrane that has fused with the plasma membrane during exocytosis could require the modification of surface protein. Vesicle recycling has been studied in detail in several neural and secretory tissues (Kelly et al., 1979; Zimmerman, 1979; Holtzman, 1981; Meldolesi and Ceccarelli, 1981), and there appear to be two different modes of membrane retrieval. At low rates of stimulation, synaptic vesicles are recaptured and recycled as small vesicles, without any morphologically obvious intervening steps (Ceccarelli et al., 1973; Zimmerman and Denston, 1977). At high rates of stimulation, large pieces of membrane are pinched in to become intracellular cisternae, which are then degraded or recycled to synaptic vesicles (Heuser and Reese, 1979). The pinched-in membrane may fuse with cytoplasmic lysosomes (Schwartz et al., 1979). The cisternal, or vacuolar, type of membrane retrieval has been seen in neurons treated with black widow spider venom (Clark et al., 1972; S. C. Landis and K. J. Sweadner, unpublished observation), veratridine (Fried and Blaustein, 1978), and barium (Liscum et al., 1982), some of the same conditions used in this study.

The correlation of surface protein release with cisternal or vacuolar membrane recapture is supported by the effects of calcium and its analogues. The recapture of membrane has been shown to require extracellular calcium in the neuromuscular junction treated with low levels of black widow spider venom (Ceccarelli and Hurlbut, 1980) and in parotid acinar cells (Koike and Meldolesi, 1981). Barium enhances transmitter release (Douglas et al., 1961) and enhances the retrieval of membrane by vacuoles (Liscum et al., 1982). Lanthanum at low concentrations blocks the evoked release of transmitter, presumably by blocking the calcium channel, but at high concentrations it elicits transmitter release and blocks the retrieval of membrane (Heuser and Miledi, 1971; Miledi et al., 1980). All of these effects parallel the observed effects on surface protein release. Cobalt depresses membrane recycling in photoreceptors, but this is thought to be due principally to its ability to block calcium channels and hence block transmitter release (Evans et al., 1978). Cobalt was found by Liscum et al. (1982) to reduce barium-stimulated vacuolar membrane retrieval in photoreceptors only at high concentrations (5 $\mathrm{mM})$; at lower concentrations $(1.2 \mathrm{mM})$, it had no effect, indicating that it is probably not as potent an inhibitor of retrieval as lanthanum. Cobalt inhibited the release of $\mathrm{S} 2$ and $\mathrm{S} 4$ elicited by black widow spider venom and A23187, but not that elicited by pCMBS. Since pCMBS causes the most rapid transmitter release of all of the agents used, the concentration of cobalt used ( 2 mM) may not have been enough to block membrane internalization. 
The mechanism of release, whether by the pinching off of membrane fragments or the shedding of proteins individually or as aggregates, is addressed in the accompanying paper (Sweadner, 1983). A hydrodynamic analysis of the size and shape of the proteins, before and after their release, is used to reach the conclusion that they are released as soluble monomers.

\section{References}

Akeson, R., and W. -C. Hsu (1978) Identification of a high molecular weight nervous system specific cell surface glycoprotein on murine neuroblastoma cells. Exp. Cell Res. 115: $367-377$.

Ames, G. F. -L., and K. Nikaido (1976) Two-dimensional gel electrophoresis of membrane proteins. Biochemistry 15: 616623.

Baba, A., and J. R. Cooper (1980) The action of black widow spider venom on cholinergic mechanisms in synaptosomes. J. Neurochem. 34: 1369-1379.

Baba, A., J. S. Fisherman, and J. R. Cooper (1979) Action of sulfhydryl reagents on cholinergic mechanisms in synaptosomes. Biochem. Pharmacol. 28: 1879-1883.

Baudry, M., M. C. Bundman, E. K. Smith, and G. S. Lynch (1981) Micromolar calcium stimulates proteolysis and glutamate binding in rat brain synaptic membranes. Science 212: 937-938.

Bonner, W. M., and R. A. Laskey (1974) A film detection method for tritium labelled proteins and nucleic acids in polyacrylamide gels. Eur. J. Biochem. 46: 83-88.

Braun, S. J., K. J. Sweadner, and P. H. Patterson (1981) Neuronal cell surfaces: Distinctive glycoproteins of cultured adrenergic and cholinergic sympathetic neurons. J. Neurosci. 1: $1397-1406$.

Carmody, J. J. (1978) Enhancement of acetylcholine secretion by two sulfhydryl reagents. Eur. J. Pharmacol. 47: 457-460.

Ceccarelli, B., and W. P. Hurlbut (1980) $\mathrm{Ca}^{2+}$-dependent recycling of synaptic vesicles at the frog neuromuscular junction. J. Cell Biol. 87: 297-303.

Ceccarelli, B., W. P. Hurlbut, and A. Mauro (1973) Turnover of transmitter and synaptic vesicles at the frog neuromuscular junction. J. Cell Biol. 57: 499-524.

Charlton, M. P., C. S. Thompson, H. L. Atwood, and B. Farnell (1980) Synaptic transmission and intracellular sodium: Ionophore induced sodium loading of nerve terminals. Neurosci. Lett. 16: 193-196.

Chen, K. Y., and C. A. Rinehart Jr. (1982) Identification of exposed surface glycoprotein in undifferentiated and differentiated mouse N-18 neuroblastoma cells. Biochim. Biophys. Acta 685: 61-70.

Chun, L. L. Y., P. H. Patterson, and H. Cantor (1980) Preliminary studies on the use of monoclonal antibodies as probes for sympathetic development. J. Exp. Biol. 89: 73-83.

Chuong, C. -M., D. A. McClain, P. Streit, and G. M. Edelman (1982) Neural cell adhesion molecules in rodent brains isolated by monoclonal antibodies with cross-species reactivity. Proc. Natl. Acad. Sci. U. S. A. 79: 4234-4238.

Clark, A. W., W. P. Hurlbut, and A. Mauro (1972) Changes in the fine structure of the neuromuscular junction of the frog caused by black widow spider venom. J. Cell Biol. 52: 1-14.

Cushley, W., B. E. H. Coupar, C. A. Mickelson, and A. R. Williamson (1982) A common mechanism for the synthesis of membrane and secreted immunoglobulin alpha, gamma and mu chains. Nature 298: 77-79.

Douglas, W. W., D. W. Lywood, and R. W. Straub (1961) The stimulant effect of barium on the release of acetylcholine from the superior cervical ganglion. J. Physiol. (Lond.) 156: $515-522$.
Estridge, M., and R. Bunge (1978) Compositional analysis of growing axons from rat sympathetic neurons. J. Cell Biol. 79: $138-155$

Evans, J. A., D. C. Hood, and E. Holtzman (1978) Differential effects of cobalt ions on rod and cone synaptic activity in the isolated frog retina. Vision Res. 18: 145-151.

Fried, R. C., and M. P. Blaustein (1978) Retrieval and recycling of synaptic vesicle membrane in pinched-off nerve terminals (synaptosomes). J. Cell Biol. 78: 685-700.

Goridis, C., M. A. Joher, M. Hirsch, and M. Schachner (1978) Cell surface proteins of cultured brain cells and their recognition by anti-cerebellum (anti-NS-4) antiserum. J. Neurochem. 31: 531-539.

Goridis, C., M. Hirsch, M. Dosetto, and E. Baechler (1980) Identification and characterization of two surface glycoproteins on cultured cerebellar cells. Brain Res. 182: 397-414.

Greene, L. A., and A. S. Tishler (1976) Establishment of a noradrenergic clonal line of rat adrenal pheochromocytoma cells which respond to nerve growth factor. Proc. Natl. Acad. Sci. U. S. A. 73: 2424-2428.

Hawrot, E., and P. H. Patterson (1979) Long-term culture of dissociated sympathetic neurons. Methods Enzymol. 58: 574584.

Heuser, J., and R. Miledi (1971) Effect of lanthanum ions on function and structure of frog neuromuscular junction. Proc. R. Soc. Lond. Biol. 179: 247-260.

Heuser, J. E., and T. S. Reese (1979) Synaptic vesicle exocytosis capture by quick freezing. In The Neurosciences: Fourth Study Program, F. O. Schmitt and F. G. Worden, eds., pp. 573-600, MIT Press, Cambridge, MA.

Hirn, M., M. Pierres, H. Deagostini-Bazin, M. Hirsch, and C. Goridis (1981) Monoclonal antibody against cell surface glycoprotein of neurons. Brain Res. 214: 433-439.

Hoffman, S., B. C. Sorkin, P. C. White, R. Brackenbury, R. Mailhammer, U. Rutishauser, B. A. Cumningham, and G. M. Edelman (1982) Chemical characterization of a neural cell adhesion molecule purified from embryonic brain membranes. J. Biol. Chem. 257: 7720-7729.

Holtzman, E. (1981) Membrane circulation: An overview. Methods Cell Biol. 23: 379-397.

Howard, B. D., and C. B. Gunderson, Jr. (1980) Effects and mechanisms of polypeptide neurotoxins that act presynaptically. Annu. Rev. Pharmacol. Toxicol. 20: 307-336.

Hubbard, A. L., and Z. A. Cohn (1976) Specific labels for cell surfaces. In Biochemical Analysis of Membranes, A. $\mathrm{H}$. Maddy, ed., pp. 427-501, Chapman and Hall, London.

Hubbard, S. C., and R. J. Ivatt (1981) Synthesis and processing of asparagine-linked oligosaccharides. Annu. Rev. Biochem. 50: $555-583$.

Ivarie, R. D., and P. A. Jones (1979) A rapid sensitive assay for specific protein synthesis in cells and in cell-free translations: Use of Staphylococcus aureus as an adsorbent for immune complexes. Anal. Biochem. 97: 24-35.

Jorgensen, O. S., A. Delouvee, J. -P. Thiery, and G. Edelman (1980) The nervous system specific protein D2 is involved in adhesion among neurites from cultured rat ganglia. FEBS Lett. 111: 39-42.

Kelly, R. B., J. W. Deutsch, S. S. Carlson, and J. A. Wagner (1979) Biochemistry of neurotransmitter release. Annu. Rev. Neurosci. 2: 399-446.

Koike, H., and J. Meldolesi (1981) Post-stimulation retrieval of luminal surface membrane in parotid acinar cells is calcium-dependent. Exp. Cell Res. 134: 377-388.

Laemmli, U. K. (1970) Cleavage of structural proteins during the assembly of the head of bacteriophage T4. Nature 227: 680-685.

Lee, V. M., L. A. Greene, and M. L. Shelanski (1981) Identification of neural and adrenal medullary surface membrane 
glycoproteins recognized by antisera to cultured rat sympathetic neurons and PC12 pheochromocytoma cells. Neuroscience 6: 2773-2786.

Liscum, L., P. J. Hauptman, D. C. Hood, and E. Holtzman (1982) Effect of barium and tetraethylammonium on membrane circulation in frog retinal photoreceptors. J. Cell Biol. 95: 296-309.

Littauer, U. Z., M. Y. Giovanni, and M. C. Glick (1980) A glycoprotein from neurites of differentiated neuroblastoma cells. J. Biol. Chem. 255: 5448-5453.

McGuire, J. C., L. A. Greene, and A. V. Furano (1978) NGF stimulates incorporation of fucose or glucosamine into an external glycoprotein in cultured rat $\mathrm{PC} 12$ pheochromocytoma cells. Cell 15: 357-365.

Meiri, H., S. D. Erulkar, T. Lerman, and R. Rahaminoff (1981) The action of the sodium ionophore, monensin, on transmitter release at the frog neuromuscular junction. Brain Res. 204: 204-208.

Meldolesi, J., and B. Ceccarelli (1981) Exocytosis and membrane recycling. Philos. Trans. R. Soc. Lond. Biol. 296: 5565.

Miledi, R., P. C. Molenaar, and R. L. Polak (1980) The effect of lanthanum ions on acetylcholine in frog muscle. J. Physiol. (Lond.) 309: 199-214.

Musick, J. R. (1979) Correlated release of acetylcholine and protein from the neuromuscular junction. Am. J. Physiol. 236: C225-C232.

O'Farrell, P. H., and P. Z. O'Farrell (1976) Two-dimensional polyacrylamide gel electrophoretic fractionation. Methods Cell Biol. 16: 107-120.

Ohta, M., T. Narahashi, and R. F. Keeler (1973) Effects of veratrum alkaloids on membrane potential and conductance of squid and crayfish giant axons. J. Pharmacol. Exp. Ther. 184: $143-154$.

Patterson, P. H., L. F. Reichardt, and L. L. Y. Chun (1976) Biochemical studies on the development of primary sympathetic neurons in cell culture. Cold Spring Harbor Symp. Quant. Biol. 40: 389-397.

Pressman, B. C. (1976) Biological application of ionophores. Annu. Rev. Biochem. 45: 501-530.

Rodemann, H. P., L. Waxman, and A. L. Goldberg (1982) The stimulation of protein degradation in muscle by $\mathrm{Ca}^{++}$is mediated by prostaglandin $\mathrm{E}_{2}$ and does not require the $\mathrm{Ca}^{++}$ activated protease. J. Biol. Chem. 257: 8716-8723.

Rohrer, H., and M. Schachner (1980) Surface proteins of cultured mouse cerebellar cells. J. Neurochem. 35: 792-803.

Rothbard, J. B., R. Brackenbury, B. A. Cunningham, and G. M. Edelman (1982) Differences in the carbohydrate structures of neural cell-adhesion molecules from adult and embryonic chicken brains. J. Biol. Chem. 257: 11064-11069.

Rotundo, R. L., and D. M. Fambrough (1980) Synthesis, transport, and fate of acetylcholine esterase in cultured chick embryo muscle cells. Cell 22: 583-594.
Salton, S. R. J., C. Richter-Landsberg, L. A. Greene, and M. L. Shelanski (1983) Nerve growth factor-inducible large external (NILE) glycoprotein: Studies of a central and peripheral neuronal marker. J. Neurosci. 3: 441-454.

Schneider, F. H., A. D. Smith, and H. Winkler (1967) Secretion from the adrenal medulla: Biochemical evidence for exocytosis. Brit. J. Pharmacol. Chemother. 31: 94-104.

Schwab, M., and S. C. Landis (1981) Membrane properties of cultured rat sympathetic neurons: Morphological studies of adrenergic and cholinergic differentiation. Dev. Biol. 84: 6778.

Schwartz, J. H., L. J. Shkolnik, and D. J. Goldberg (1979) Specific association of neurotransmitter with somatic lysosomes in an identified serotonergic neuron of Aplysia californica. Proc. Natl. Acad. Sci. U. S. A. 76: 5967-5971.

Showell, H. J., P. H. Naccache, R. I. Sha'afi, and E. L. Becker (1977) Effect of extracellular $\mathrm{K}^{+}, \mathrm{Na}^{+}$, and $\mathrm{Ca}^{++}$on lysosomal enzyme secretion from polymorphonuclear leukocytes. J. Immunol. 119: 804-811.

Smith, A. D., W. P. De Potter, E. J. Moerman, and A. F. De Schaepdryver (1970) Release of dopamine $\beta$-hydroxylase and chromogranin A upon stimulation of the splenic nerve. Tissue Cell 2: 547-568.

Stallcup, W. B., L. S. Arner, and J. M. Levine (1983) An antiserum against the $\mathrm{PC} 12$ cell line defines cell surface antigens specific for neurons and Schwann cells. J. Neurosci. 3: $53-68$.

Sweadner, K. J. (1981) Environmentally regulated expression of soluble extracellular proteins of sympathetic neurons. J. Biol. Chem. 256: 40634070.

Sweadner, K. J. (1983) Size, shape, and solubility of a class of releasable cell surface proteins of sympathetic neurons. J. Neurosci. 3: 2518-2524.

Sweadner, K. J., and P. H. Patterson (1981) Neuronal surface protein release accompanies transmitter release. Soc. Neurosci. Abstr. 7: 709.

Thiery, J. -P., R. Brackenbury, U. Rutishauser, and G. M. Edelman (1977) Adhesion among neural cells of the chick embryo. II. Purification and characterization of a cell adhesion molecule from neural retina. J. Biol. Chem. 252: 68416845.

Weiss, G. B. (1974) Cellular pharmacology of lanthanum. Annu. Rev. Pharmacol. Toxicol. 14: 343-354.

Zimmerman, H. (1979) Vesicle recycling and transmitter release. Neuroscience 4: 1773-1804.

Zimmerman, H., and C. R. Denston (1977) Recycling of synaptic vesicles in the cholinergic synapses of the Torpedo electric organ during induced transmitter release. Neuroscience 2: 695-714.

Zurn, A. D. (1982) Identification of glycolipid binding sites for soybean agglutinin and differences in the surface glycolipids of cultured adrenergic and cholinergic sympathetic neurons. Dev. Biol. 94: 483-498. 